\title{
list of characters
}

Agastya. The forest saint who gave Rama a bow and arrow.

AGNI. The fire god.

aHALYA. The most beautiful woman ever created.

airavata. Indra's elephant.

anUSUYA. Atri's wife, who gave Sita ornaments in the forest.

angada. The monkey prince.

ANJANA. Hanuman's mother.

ARJUNA OF A

THOUSAND ARMS. The Haihaya king.

ARUNA. Charioteer of the sun.

aswapatr. Kaikeyi's father, the Kekaya king.

ATRI. A saint dwelling near the Vindhya mountains.

BHARADWAJA. A hermit of the woods who received Rama; he lived on to become the father of Drona.

BHARATA. Dasaratha's son and Rama's brother; no relation to the namesake of the Kurus.

BRAнma. Grandfather and Creator of the worlds. 
CHANDra. The Moon.

chitraratha. The Gandharva king, lord of heaven's musicians.

DADHICA. An ancient warrior, revived by Indra.

DADHimuKha. A monkey, keeper of Sugriva's Honey Park DASARATHA. Rama's father.

DEvi. Shiva's consort.

DUNDHUVI. A giant buffalo.

DURVASAS. A grim ascetic.

GARUDA. King of Birds, ridden by Narayana.

gautama. A sage, Ahalya's husband.

gunA. The hunter king.

hanUman. The monkey, Son of the Wind.

hema. An Apsarasa, Queen Mandodari's mother.

himavan. The Lord of the Himalya, Devi's father.

ILVAla. A cannibal.

INDRA. The Rain God, King of heaven.

INDRAJIT. Ravana's son.

INDRANI. Indra's wife.

Jambavan. King of the Bears.

Jambumali. Prahasta's son.

JANAKA. The Videha King, Sita's father.

jatayu. The Dandaka vulture King.

KADRU. One of Kashyapa's wives, mother of the snakes.

KAIKASI. Sumali's daughter and wife of Nishrava.

KAIKEYI. Bharata's mother.

Kala. Time.

xama. The god of love. He is bodiless.

KASHYAPA. An ancient sage.

KAUSALYA. Rama's mother. 
KHARA. Demon commander of Dandaka Forest.

KUMBHAKARNA. Ravana's giant brother.

KUSA. Rama's elder son.

LAKSHMANA. Rama's brother, Sumitra's son.

LAKshmi. The goddess of good fortune and Narayana's consort.

LAVA. Rama's younger son.

MAINAKA. A live, golden submarine mountain.

mali. One of the three demons for whom Lanka was built.

MaLYAVAN. Mali's brother.

MANDAKARNI. A sage dwelling in a lake.

MANDODARI. Queen of Lanka.

MANIBHADRA. The Yaksha king.

MANTHARA. Kaikeyi's old nurse.

MARICHA. The demon who became a golden deer.

MATALI. Indra's charioteer.

MatANGA. The saint who lived by Rishyamukha Hill.

MAYA THE

ASURA. The divine artist of illusion, a magician.

MaYAVI. Dundhuvi's son.

MEGHANADA. Indrajit's birth name.

Nala. The monkey who built Rama's bridge to Lanka.

NALAKUBARA. Son of the god of wealth.

NANDIN. Shiva's white bull.

NARADA. A heavenly sage born from Brahma's mind. narayana. The great god Vishnu who preserves the three worlds.

PARVATI. A name of Devi.

PRAHASTA. Ravana's general. 
PULASTYA. One of Brahma's sons. He impregnates Trinavindu's daughter.

PULOMA. Indrani's father.

PUSHPAKA. A huge aerial chariot.

RAHU. The Asura whose living head, cut off at the neck, causes the eclipse of sun and moon by swallowing them in the sky.

RAMA.

RAMBHA. A lovely nymph.

Ravana. The demon king.

riksharaja. The first monkey. He changes sex.

Ruma. Sugriva's wife, queen of Kishkindha.

SAMPATI. Jatayu's brother.

SAMUDRA. Ocean.

SaRAna. Demon spy of Ravana.

SARASWATI. Goddess of speech.

SARDULA. Demon spy of Ravana.

SATRUGHNA. Rama's brother, Sumitra's son.

SAUNAKa. Who hears the story.

sauti. The storyteller.

SAVARI. A female hermit, friendly to Rama.

SHIVA. The great god whose third eye will burn the universe.

sinHika. A female monster.

sita. Rama's wife.

subahu. A demon killed by Lakshmana.

SUGriva. The monkey king.

SUKA. Ravana's minister.

sUKesA. Father of Mali, Sumali and Malyavan.

SUKRA. Indrajit's preceptor.

sumali. The third of the three Rakshasas who first lived in Lanka.

SUMANTrA. The royal charioteer of Ayodhya.

sumitra. Mother of Satrughna and Lakshmana.

SURABHI. The cow of plenty. 
SURPANAKHA. Ravana's sister.

SURYA. The Sun.

SWAYAMPRABHA. An enchantress.

TARA. Wife of the monkey king Vali.

TRIJATA. The Rakshasi who befriended Sita.

TRINAVINDU. Father of a nymph.

TUMBURU. A Gandharva.

UCCHAIHSRAVAS. A famous horse.

vaishravana. The treasure king.

vajRa-Danshtra. Thunder-Tooth.

VALAKHILYAS. Benign little deities floating in the air.

vali. Sugriva's brother.

valmiki. Who invented poetry.

VARUNA. God of the waters and guardian of the west and of the worlds undersea.

vasishtha. Dasaratha's priest.

vasuKı. King of Serpents.

vatapI. A cannibal in the Vindhya mountains.

vaYu. The wind god.

vIBHISHANA. Ravana's brother.

viDYUJ-JIHVA. Lightning-Tongue.

vinata. One of Kashyapa's wives, mother of Garuda.

VIRADHA. A long-armed monster.

visHNu. The great god Narayana, pervading the universe, moving in the waters, preserving and restoring life.

visWAKarman. Heavenly architect and lord of the arts.

visWAMITRA. Who took Rama to protect him in the forest.

YAMA. God of death.

YUDHAJIT. Bharata's uncle, prince of Kekaya and Kaikeyi's brother. 

Oh Man, I am the demon warrior Indrajit, hard to see. I fight invisibly, hidden by enchantment from your sight. I attack behind the wild winds of evil thought; I put out many lights left unguarded. I know you, and good deeds done in life are your only shield when you must die and go alone past me to another world. You may hide at night from the Sun, but never from your own heart-where lives Lord Narayana. The entire worlds are watching your deeds, and therefore forgiveness is Dharma.

Valmiki the Poet looked down into water held cupped in his hand and saw into the past. Before he looked, he thought the world was sweet poison. Men seemed to be living in lies, not knowing where their ways went. The days seemed made of ignorance and doubt, and cast from deception and illusion. But in the water he saw-a dream, a chance, and a great adventure. Valmiki trusted the True and forgot the rest; he found the whole universe like a bright jewel set firm in forgiving and held fast by love.

Widen your heart. Abandon anger. Believe me, your few days are numbered; make one fast choice now and no second!

Come, clear your heart and quickly walk with me into Brahma, while there is time. 
